\title{
Genetic diversity of selected genes that are potentially economically important in feral sheep of New Zealand
}

\author{
Grant W McKenzie', Johanna Abbott², Huitong Zhou', Qian Fang ${ }^{1}$, Norma Merrick', Rachel H Forrest ${ }^{3}$, \\ J Richard Sedcole ${ }^{1}$, Jonathan G Hickford ${ }^{1 *}$
}

\begin{abstract}
Background: Feral sheep are considered to be a source of genetic variation that has been lost from their domestic counterparts through selection.

Methods: This study investigates variation in the genes KRTAP1-1, KRT33, ADRB3 and DQA2 in Merino-like feral sheep populations from New Zealand and its offshore islands. These genes have previously been shown to influence wool, lamb survival and animal health.

Results: All the genes were polymorphic, but no new allele was identified in the feral populations. In some of these populations, allele frequencies differed from those observed in commercial Merino sheep and other breeds found in New Zealand. Heterozygosity levels were comparable to those observed in other studies on feral sheep. Our results suggest that some of the feral populations may have been either inbred or outbred over the duration of their apparent isolation.

Conclusion: The variation described here allows us to draw some conclusions about the likely genetic origin of the populations and selective pressures that may have acted upon them, but they do not appear to be a source of new genetic material, at least for these four genes.
\end{abstract}

\section{Background}

It is thought that livestock genetic variation has decreased through breed substitution and crossing of local and global breeds [1]. Accordingly, interest in feral populations has increased because they are potential sources of genetic variation that may have been lost in commercial sheep flocks $[2,3]$. It has been argued that reintroducing genetic variability could enhance production in commercial breeds [4].

New Zealand (NZ) has eleven feral sheep populations either on the mainland, or on offshore islands [5]. The mainland populations originated from farmed sheep [6], while those on offshore islands either originated from farms, or were liberated as a food source for mariners [7].

\footnotetext{
* Correspondence: Jon.Hickford@lincoln.ac.nz

'Department of Agricultural Science, Faculty of Agriculture and Life Sciences,

PO Box 84, Lincoln University, Lincoln 7647, New Zealand

Full list of author information is available at the end of the article
}

These populations have been described previously [1,4,6,8-13].

In this study, the level of genetic variation of four genes was determined in order to ascertain whether the isolation of these flocks had preserved greater genetic diversity compared to their commercial counterparts in NZ. These four genes are located on three different chromosomes i.e. KRTAP1-1 (chromosome 11; a keratin-associated protein gene that encodes a protein KAP1-1 commonly found in wool), KRT33 (chromosome 11; encoding wool keratin K33), ADRB3 (chromosome 26; encoding the seven-transmembrane domain beta- 3 adrenergic receptor ADRB3) and $D Q A 2$ (chromosome 20; encoding a class II major histocompatibility complex (MHC) protein DQA2).

Previous studies have reported that variations in the keratin and keratin-associated protein genes, including the ones above, influence many wool properties including fibre diameter [14], staple strength [15], mean staple length [16] and the brightness of wool [16]. Accordingly,

\section{() Biomed Central}


given the wide phenotypic variation seen in the wool of feral sheep $[6,8]$, one might expect to see increased variation in these genes.

Neonatal lamb mortality, particularly in Merino sheep, represents a large loss to the NZ sheep industry. Allelic variation in $A D R B 3$ has been associated with survival in various sheep breeds [17], thus it might be expected that previously reported or new alleles would be found at a higher frequency in feral populations routinely exposed to harsh environmental conditions.

It has been reported that feral sheep may have an increased resistance to a number of diseases. This resistance could imply that variation in key immune function genes such as the highly polymorphic MHC genes is important, as it plays a role in the immune response to pathogens and parasites [18-21].

Collectively the four genes chosen here cover a variety of different animal traits that could be associated with variation in the ability to survive in remote and potentially more severe environments, and where feed availability was probably reduced relative to farmed sheep.

\section{Materials and methods}

\section{Sheep and DNA sources}

Ten feral flocks and two reference flocks (non-feral) were investigated in this study (Table 1). Genomic DNA from these sheep was obtained from whole blood collected on FTA Classic Cards (Whatman BioScience, Middlesex, UK) following the manufacturer's instructions. Reference flock allele frequencies (see Tables 2 and 3) were sourced from published data [17,22-24] and from NZ commercial sheep DNA samples stored at Lincoln University.

\section{PCR amplification and genotyping}

PCR amplifications and genotyping approaches were carried out using previously described methods $[17,24-26]$

\section{Data analysis}

Allele frequencies, number of alleles, observed heterozygosity $\left(H_{O}\right)$, expected heterozygosity $\left(H_{E}\right.$ with a Levene's correction) and coefficient of inbreeding $\left(F_{\mathrm{IS}}\right)$ estimates based on the method of Weir and Cockerham [27] were determined using GENEPOP version 4.0.7 [28]. This software was also used to determine deviations from Hardy-Weinberg equilibrium (HWE) using the Exact Test with a Markov Chain Method [29] (10 batches, 5000 iterations per batch and a dememorization number of 10000$)$. Corrections for multiple significance tests were performed using Fisher's method and by applying a sequential Bonferroni type correction [29]. $F_{\text {IS }}$ estimates were calculated across all the populations and genes (global $F_{\mathrm{IS}}$ ) and for individual populations and genes. Allelic richness, a measure of genetic diversity at a single locus, was determined using FSTAT version 2.9.3 [30] and included rarefaction to correct for sample size variation [31].

Allele frequencies for each feral population were compared to those of Merino sheep sourced from NZ

Table 1 Origin of sheep populations and sample numbers $(\mathrm{N})$

\begin{tabular}{|c|c|c|c|c|}
\hline \multirow{2}{*}{$\begin{array}{l}\text { Flock type } \\
\text { Feral }\end{array}$} & \multicolumn{2}{|c|}{ Flock location } & \multirow{2}{*}{$\begin{array}{l}\text { Origin/Breed/Type } \\
\text { Australia/Merino/unknown }\end{array}$} & \multirow{2}{*}{$\frac{\mathbf{N}}{17}$} \\
\hline & Offshore & $\begin{array}{l}\text { Arapawa } \\
\text { Island I }\end{array}$ & & \\
\hline & & $\begin{array}{l}\text { Arapawa } \\
\text { Island || }\end{array}$ & Australia/Merino/unknown & 61 \\
\hline & & $\begin{array}{l}\text { Chatham } \\
\text { Island }\end{array}$ & Australia/Merinos/Saxon & 22 \\
\hline & & Pitt Island & Australia/Merinos/Saxon & 519 \\
\hline & & $\begin{array}{l}\text { Campbell } \\
\text { Island }\end{array}$ & Australia/Merino $\times$ longwool & 105 \\
\hline & Mainland & Woodstock & Australia/Merino/unknown & 31 \\
\hline & & Hokonui I & Tasmania/Merino/Saxon & 12 \\
\hline & & Hokonui II & Tasmania/Merino/Saxon & 73 \\
\hline & & Herbert & Tasmania/Merino/unknown & 24 \\
\hline & & Mohaka & Unknown/Merino/unknown & 14 \\
\hline & & & & 878 \\
\hline \multirow[t]{2}{*}{$\begin{array}{l}\text { Domestic } \\
\text { reference flocks }\end{array}$} & Mainland & Merino $^{1}$ & New Zealand/Merino/unknown & $\begin{array}{l}20 \\
123\end{array}$ \\
\hline & & All breeds ${ }^{2}$ & $\begin{array}{l}\text { Corriedale, Poll Dorset, Suffolk, Borderdale, Coopworth, } \\
\text { Dorset Down } \times \text { Coopworth, Merino } \times \text { Coopworth, } \\
\text { Merino } \times \text { Polwarth, Merino, Polwarth, Dorset Down and Hampshire, NZ Romney, Awassi, Finnish } \\
\text { Landrace and other NZ crossbred sheep }\end{array}$ & $\begin{array}{l}43 \\
737\end{array}$ \\
\hline
\end{tabular}


Table 2 Within-population sample sizes (N), number of alleles identified (n) and allele frequencies for KRTAP1-1, KRT33 and ADRB3

\begin{tabular}{|c|c|c|c|c|c|c|c|c|c|c|}
\hline \multicolumn{11}{|c|}{ KRTAP1-1 } \\
\hline Population & $\mathrm{N}$ & $\mathrm{n}$ & $A$ & $B$ & $C$ & & & & & \\
\hline Arapawa Island I & 14 & 3 & $0.43^{\mathrm{a}}$ & $0.46^{a}$ & $0.11^{b c}$ & & & & & \\
\hline Arapawa Island II & 59 & 2 & - & $0.93^{c}$ & $0.07^{b c}$ & & & & & \\
\hline Chatham Island & 22 & 2 & $0.18^{\mathrm{ab}}$ & $0.82^{\mathrm{ab}}$ & - & & & & & \\
\hline Pitt Island & 477 & 2 & - & $0.85^{b}$ & $0.15^{\mathrm{a}}$ & & & & & \\
\hline Campbell Island & 97 & 3 & $0.02^{c}$ & $0.82^{b}$ & $0.16^{\mathrm{a}}$ & & & & & \\
\hline Woodstock & 28 & 3 & $0.29^{\mathrm{a}}$ & $0.68^{\mathrm{ab}}$ & $0.04^{\mathrm{b}}$ & & & & & \\
\hline Hokonui I & 11 & 2 & - & $0.82^{\mathrm{ab}}$ & $0.18^{\mathrm{bc}}$ & & & & & \\
\hline Hokonui II & 65 & 2 & - & $0.88^{b}$ & $0.12^{b c}$ & & & & & \\
\hline Herbert & 23 & 2 & $0.15^{\mathrm{ab}}$ & $0.85^{b}$ & - & & & & & \\
\hline Mohaka & 6 & 2 & - & $0.83^{\mathrm{ab}}$ & $0.17^{\mathrm{bc}}$ & & & & & \\
\hline Merino reference flock & 795 & 3 & $0.23^{\mathrm{a}}$ & $0.7^{\mathrm{a}}$ & $0.07^{\mathrm{b}}$ & & & & & \\
\hline All Breeds reference flock & 309 & 3 & $0.06^{b}$ & $0.80^{b}$ & $0.14^{c}$ & & & & & \\
\hline \multicolumn{11}{|c|}{ KRT33 } \\
\hline Population & $\mathrm{N}$ & $\mathrm{n}$ & $A$ & $B$ & $C$ & $D$ & $E$ & & & \\
\hline Arapawa Island I & 13 & 5 & $0.04^{a}$ & $0.19^{\mathrm{ab}}$ & & $0.46^{\mathrm{ac}}$ & $0.19^{\mathrm{a}}$ & & & \\
\hline Arapawa Island II & 60 & 3 & - & - & $0.40^{\mathrm{a}}$ & $0.23^{\mathrm{a}}$ & $0.38^{\mathrm{b}}$ & & & \\
\hline Chatham Island & 22 & 5 & $0.32^{\mathrm{b}}$ & $0.07^{\mathrm{a}}$ & $0.16^{\mathrm{bc}}$ & $0.23^{c}$ & $0.23^{\mathrm{a}}$ & & & \\
\hline Pitt Island & 471 & 4 & $0.04^{\mathrm{a}}$ & - & $0.05^{c}$ & $0.43^{c}$ & $0.48^{\mathrm{b}}$ & & & \\
\hline Campbell Island & 92 & 5 & $0.02^{a}$ & $0.42^{b}$ & $0.01^{a}$ & $0.10^{b}$ & $0.45^{\mathrm{b}}$ & & & \\
\hline Woodstock & 30 & 5 & $0.07^{c}$ & $0.18^{c}$ & $0.30^{\mathrm{b}}$ & $0.33^{c}$ & $0.12^{\mathrm{a}}$ & & & \\
\hline Hokonui I & 11 & 4 & $0.23^{b c}$ & $0.36^{\mathrm{b}}$ & - & $0.23^{b c}$ & $0.18^{\mathrm{a}}$ & & & \\
\hline Hokonui II & 67 & 5 & $0.27^{b}$ & $0.28^{b}$ & $0.14^{b}$ & $0.21^{a}$ & $0.10^{\mathrm{a}}$ & & & \\
\hline Herbert & 24 & 5 & $0.13^{\mathrm{bc}}$ & $0.35^{\mathrm{b}}$ & $0.31^{b}$ & $0.19^{b}$ & $0.02^{c}$ & & & \\
\hline Mohaka & 14 & 2 & - & - & - & $0.43^{c}$ & $0.57^{\mathrm{b}}$ & & & \\
\hline Merino reference flock & 739 & 5 & $0.26^{b}$ & $0.36^{\mathrm{b}}$ & $0.19^{b}$ & $0.04^{b}$ & $0.15^{\mathrm{a}}$ & & & \\
\hline All Breeds reference flock & 967 & 5 & $0.08^{c}$ & $0.04^{a}$ & $0.05^{c}$ & $0.40^{c}$ & $0.43^{b}$ & & & \\
\hline \multicolumn{11}{|c|}{ ADRB3 } \\
\hline Population & $\mathrm{N}$ & $n$ & $A^{1}$ & $B^{2}$ & $c^{3}$ & $D^{4}$ & $E^{1}$ & $F^{2}$ & $G^{5}$ & $H^{5}$ \\
\hline Arapawa Island I & 17 & 4 & $0.32^{b c}$ & - & $0.35^{b c}$ & - & $0.24^{\mathrm{bc}}$ & $0.09^{\mathrm{bc}}$ & - & - \\
\hline Arapawa Island II & 60 & 4 & $0.17^{\mathrm{a}}$ & - & $0.04^{\mathrm{a}}$ & - & $0.39^{\mathrm{a}}$ & $0.40^{\mathrm{a}}$ & - & - \\
\hline Chatham Island & 22 & 4 & $0.27^{\mathrm{bc}}$ & - & $0.16^{c}$ & - & $0.55^{\mathrm{a}}$ & $0.02^{c}$ & - & - \\
\hline Pitt Island & 499 & 6 & $0.20^{\mathrm{a}}$ & $0.04^{a}$ & $0.23^{c}$ & - & $0.28^{\mathrm{a}}$ & $0.25^{\mathrm{a}}$ & $0.002^{\mathrm{a}}$ & - \\
\hline Campbell Island & 102 & 4 & $0.66^{\mathrm{a}}$ & $0.17^{\mathrm{a}}$ & $0.1^{c}$ & - & - & $0.01^{\mathrm{a}}$ & - & - \\
\hline Woodstock & 30 & 4 & $0.28^{\mathrm{bc}}$ & $0.05^{b c}$ & $0.18^{c}$ & - & - & $0.48^{\mathrm{a}}$ & - & - \\
\hline Hokonui I & 11 & 3 & $0.73^{\mathrm{a}}$ & $0.23^{b c}$ & - & - & $0.05^{\mathrm{a}}$ & - & - & - \\
\hline Hokonui II & 68 & 4 & $0.53^{\mathrm{a}}$ & $0.29^{\mathrm{a}}$ & - & - & $0.16^{\mathrm{bc}}$ & - & $0.01^{\mathrm{a}}$ & - \\
\hline Herbert & 24 & 4 & $0.77^{\mathrm{a}}$ & $0.04^{b c}$ & $0.17^{c}$ & - & - & $0.02^{\mathrm{b}}$ & & - \\
\hline Mohaka & 6 & 3 & $0.25^{\mathrm{bc}}$ & $0.08^{b c}$ & - & - & - & $0.67^{\mathrm{a}}$ & - & - \\
\hline Merino reference flock & 4484 & 6 & $0.35^{\mathrm{b}}$ & $0.02^{b}$ & $0.33^{b}$ & 0.06 & $0.20^{\mathrm{b}}$ & $0.05^{\mathrm{b}}$ & - & - \\
\hline All Breeds reference flock & 13420 & 8 & $0.37^{c}$ & $0.09^{c}$ & $0.21^{c}$ & 0.02 & $0.20^{c}$ & $0.10^{c}$ & $0.01^{b}$ & 0.004 \\
\hline
\end{tabular}


Table 3 Within population sample sizes $(\mathrm{N})$, number of alleles identified $(\mathrm{n})$ and allele frequencies for $D Q A 2^{1}$

\begin{tabular}{|c|c|c|c|c|c|c|c|c|c|c|c|}
\hline \multicolumn{12}{|c|}{$D Q A 2$ alleles } \\
\hline Population & $\mathrm{N}$ & $n$ & 06023 & 0601 & 08011 & 0901 & 0103 & 1101 & $\begin{array}{c}0102- \\
1601\end{array}$ & $\begin{array}{c}0101- \\
1401\end{array}$ & 1201 \\
\hline Arapawa Island I & 17 & 8 & $0.18^{\mathrm{a}}$ & - & $0.15^{a}$ & - & $0.06^{\mathrm{a}}$ & $0.06^{\mathrm{a}}$ & - & - & $0.03^{a}$ \\
\hline Arapawa Island II & 61 & 7 & $0.02^{\mathrm{a}}$ & $0.02^{\mathrm{a}}$ & - & - & - & - & $0.03^{\mathrm{a}}$ & $0.17^{a}$ & - \\
\hline Chatham Island & 22 & 6 & $0.23^{\mathrm{a}}$ & - & - & $0.05^{\mathrm{a}}$ & - & $0.09^{\mathrm{a}}$ & - & - & - \\
\hline Pitt Island & 519 & 13 & $0.07^{b}$ & $0.02^{\mathrm{b}}$ & - & $0.11^{\mathrm{b}}$ & $0.03^{b}$ & $0.02^{\mathrm{a}}$ & $0.04^{\mathrm{a}}$ & $0.14^{a}$ & $0.11^{b}$ \\
\hline Campbell Island & 105 & 9 & - & $0.01^{b}$ & - & - & $0.07^{\mathrm{a}}$ & $0.17^{\mathrm{b}}$ & - & $0.40^{\mathrm{b}}$ & - \\
\hline Woodstock & 31 & 10 & $0.03^{b}$ & - & - & - & $0.05^{\mathrm{a}}$ & $0.31^{b}$ & - & - & $0.24^{b}$ \\
\hline Hokonui I & 12 & 6 & $0.05^{\mathrm{a}}$ & - & $0.13^{\mathrm{a}}$ & - & $0.08^{\mathrm{a}}$ & - & - & $0.63^{b}$ & $0.04^{b}$ \\
\hline Hokonui II & 73 & 9 & $0.07^{\mathrm{a}}$ & $0.08^{\mathrm{a}}$ & $0.21^{\mathrm{b}}$ & - & $0.12^{\mathrm{a}}$ & $0.13^{\mathrm{b}}$ & - & $0.23^{\mathrm{a}}$ & $0.11^{b}$ \\
\hline Herbert & 24 & 7 & $0.06^{\mathrm{a}}$ & - & $0.35^{\mathrm{b}}$ & - & $0.02^{b}$ & $0.08^{\mathrm{a}}$ & - & $0.23^{\mathrm{a}}$ & - \\
\hline Mohaka & 8 & 2 & - & - & - & - & - & $0.94^{\mathrm{b}}$ & - & $0.06^{\mathrm{a}}$ & - \\
\hline Merino reference flock & 20123 & - & - & - & - & - & - & - & $0.04^{a}$ & - & - \\
\hline $\begin{array}{l}\text { All breeds reference } \\
\text { flock }\end{array}$ & 43737 & - & $0.11^{\mathrm{a}}$ & $0.04^{a}$ & $0.03^{\mathrm{a}}$ & $0.08^{\mathrm{a}}$ & $0.10^{\mathrm{a}}$ & $0.01^{\mathrm{a}}$ & $0.05^{\mathrm{a}}$ & $0.15^{a}$ & $0.13^{b}$ \\
\hline \multicolumn{12}{|c|}{$D Q A 2$ alleles } \\
\hline Population & & & $\begin{array}{l}08012- \\
0201\end{array}$ & $\begin{array}{c}0701- \\
1401\end{array}$ & $\begin{array}{c}0701- \\
1301\end{array}$ & $\begin{array}{c}0401- \\
1501\end{array}$ & $\begin{array}{c}0702- \\
1401\end{array}$ & 0301 & 0501 & $\begin{array}{c}0402- \\
1701\end{array}$ & $\begin{array}{r}0401- \\
1601\end{array}$ \\
\hline Arapawa Island I & & & $0.32^{\mathrm{a}}$ & - & - & - & $0.09^{b c}$ & - & $0.12^{b}$ & - & - \\
\hline Arapawa Island II & & & $0.11^{\mathrm{a}}$ & - & - & - & $0.07^{\mathrm{bc}}$ & - & $0.58^{\mathrm{a}}$ & - & - \\
\hline Chatham Island & & & $0.27^{\mathrm{a}}$ & - & - & - & $0.23^{\mathrm{a}}$ & - & $0.14^{b}$ & - & - \\
\hline Pitt Island & & & $0.002^{c}$ & - & - & - & $0.33^{\mathrm{a}}$ & $0.001^{\mathrm{a}}$ & $0.01^{\mathrm{a}}$ & $0.13^{\mathrm{a}}$ & - \\
\hline Campbell Island & & & - & - & - & - & $0.16^{\mathrm{a}}$ & $0.17^{\mathrm{a}}$ & $0.005^{a}$ & $0.02^{\mathrm{bc}}$ & $0.005^{\mathrm{a}}$ \\
\hline Woodstock & & & $0.05^{\mathrm{bc}}$ & $0.02^{a}$ & $0.02^{a}$ & $0.23^{\mathrm{a}}$ & $0.03^{\mathrm{bc}}$ & - & - & $0.03^{b c}$ & - \\
\hline Hokonui I & & & - & - & - & - & $0.08^{b c}$ & - & - & - & - \\
\hline Hokonui II & & & - & - & - & $0.01^{c}$ & $0.05^{\mathrm{bc}}$ & - & - & - & - \\
\hline Herbert & & & $0.19^{\mathrm{a}}$ & - & - & - & - & - & $0.06^{\mathrm{b}}$ & - & - \\
\hline Mohaka & & & - & - & - & - & - & - & - & - & - \\
\hline Merino Reference flock & & & $0.03^{b}$ & - & $0.001^{a}$ & $0.04^{b}$ & $0.03^{b}$ & - & - & $0.02^{b}$ & $0.05^{b}$ \\
\hline $\begin{array}{l}\text { All breeds reference } \\
\text { flock }\end{array}$ & & & $0.003^{c}$ & $0.02^{\mathrm{a}}$ & $0.002^{a}$ & $0.03^{c}$ & $0.02^{c}$ & $0.02^{b}$ & $0.06^{b}$ & $0.02^{c}$ & $0.16^{c}$ \\
\hline
\end{tabular}

${ }^{1} D Q A 2$ nomenclature [24]; ${ }^{a-c}$ allele frequency differences within columns that share no common alphabetic superscripts are significantly different $(\mathrm{P}<0.05)$, while the pair-wise comparisons that are not different are represented with different superscripts; "-" represents alleles or data not available

commercial farms [17] and to the combined allele frequencies in breeds commonly found in NZ [17,22-24]. This was undertaken to determine which groups were more closely related to each other based on "distance" measured by the Pearson $\chi^{2}$-statistic for each possible pair of breeds and their respective estimated gene frequencies.

\section{Results}

All genes investigated in this study were polymorphic and allele frequencies for each gene varied among the studied flocks (Table 2 and 3). No new allele was identified for any of the genes in any of the sheep typed in this study. All the KRTAP1-1 alleles previously described were present in the feral sheep except allele $A$ absent in four breeds, including one population from Arapawa Island (Hokonui sheep) and one from Pitt Island (Mohaka sheep), and allele $C$ absent in the populations from Herbert Forest and Chatham Island.

Previous studies have reported five KRT33 alleles [25], all of which occurred in the feral populations. Alleles $D$ and $E$ were found in all the populations whereas alleles $A$ and $B$ were absent in the sheep from Arapawa Island and the Mohaka populations, allele $C$ was absent in those from Mohaka and alleles $B$ and $C$ in those from the Pitt Island and Hokonui, respectively.

Six different $A D R B 3$ alleles were detected in the feral sheep. The lowest diversity was observed in the Mohaka population with only three alleles while it was greatest in the sheep from Pitt Island with six alleles. It is interesting to note that alleles $D$ and $H$, which occur at relatively low frequencies in other commercial breeds in NZ [17], were absent in all the feral populations. The frequency of allele $G$ is low in NZ commercial sheep and 
was only found at a low frequency in the sheep from Pitt Island and Hokonui.

The distribution of $D Q A 2$ alleles varied considerably among populations with some alleles completely absent in some populations. The lowest diversity was observed in the sheep from Mohaka with only two $D Q A 2$ alleles. Conversely, thirteen $D Q A 2$ alleles were present in the sheep from Pitt Island.

For all four genes, in most cases allele frequencies in the feral populations differed significantly ( $\mathrm{p} \leq 0.025$ ) from the frequencies in the reference flocks, most of the differences being highly significant $(p<0.001)$. The following exceptions were found: (1) frequencies of KRTAP1-1 alleles of sheep from Chatham Island $(\mathrm{p}=$ $0.113)$, Woodstock $(\mathrm{p}=0.434)$, Herbert $(\mathrm{p}=0.055)$ and Mohaka ( $\mathrm{p}=0.098$ ) were not significantly different from those of the Merino reference flock, and those of sheep from Mohaka ( $\mathrm{p}=0.673)$, Campbell Island $(\mathrm{p}=0.084)$ and Hokonui I ( $\mathrm{p}=0.454)$ were not different from those of all breeds and (2) frequencies of $A D R B 3$ alleles of sheep from the Arapawa Island I did not differ from those of either reference flock (Merino $\mathrm{p}=0.332$; All breeds $\mathrm{p}=0.771$ ).
Allelic richness, observed $\left(H_{O}\right)$ and expected $\left(H_{E}\right)$ levels of heterozygosity and coefficient of inbreeding $\left(F_{\mathrm{IS}}\right)$ are shown in Table 4. On average between 2.03 and 4.86 alleles were detected per polymorphic gene across all the populations. The lowest number of alleles was observed for the $A D R B 3$ gene (1.59) in the sheep from Arapawa Island II while the greatest number of alleles was found for KRT33 (6.12) in the Hokonui II sheep. Allelic richness was highest for KRT33 and lowest for ADRB3 in all feral populations except for the Mohaka sheep.

Observed and expected heterozygosity values ranged from a low of 0.06 observed for KRTAP1-1 to a high of 1.0 for KRT33, and a low of 0.13 for KRTAP1-1 and a high of 0.86 for $D Q A 2$, respectively. Arapawa I sheep had the highest mean estimate for $H_{O}$ and $H_{E}$ over all of the genes ( 0.73 and 0.73 , respectively), while Mohaka sheep had the lowest mean estimate for $\mathrm{Ho}$ and $\mathrm{He}$ ( 0.43 and 0.38 , respectively). Allele sharing was high between animals originating from Campbell Island and Pitt Island for KRTAP1-1 and among the Arapawa II flock of feral sheep for KRT33 and lower among the Arapawa I flock for $D Q A 2$. Finally, allele sharing among sheep from Woodstock was very low for $D Q A 2$.

Table 4 Allelic richness $(r)$, expected $\left(H_{E}\right)$ and observed $\left(H_{O}\right)$ heterozygosity, $F_{\text {IS }}{ }^{1}$ values for feral sheep populations of New Zealand

\begin{tabular}{llllllllllllllllll}
\hline Population & \multicolumn{4}{c}{ Arapawa Island I } & \multicolumn{4}{c}{ Arapawa Island II } & \multicolumn{4}{c}{ Chatham Island } & \multicolumn{4}{c}{ Pitt Island } \\
locus & $\mathbf{r}$ & $\boldsymbol{H}_{\boldsymbol{O}}$ & $\boldsymbol{H}_{\boldsymbol{E}}$ & $\boldsymbol{F}_{\mathrm{IS}}$ & $\mathbf{r}$ & $\boldsymbol{H}_{\boldsymbol{O}}$ & $\boldsymbol{H}_{\boldsymbol{E}}$ & $\boldsymbol{F}_{\mathrm{IS}}$ & $\mathbf{r}$ & $\boldsymbol{H}_{\boldsymbol{O}}$ & $\boldsymbol{H}_{E}$ & $\boldsymbol{F}_{\text {IS }}$ & $\boldsymbol{r}$ & $\boldsymbol{H}_{\boldsymbol{O}}$ & $\boldsymbol{H}_{E}$ & $\boldsymbol{F}_{\text {IS }}$ \\
\hline KRTAP1-1 & 3.72 & 0.71 & 0.61 & -0.18 & 3.30 & 0.14 & 0.13 & -0.06 & 3.17 & 0.36 & 0.30 & -0.20 & 4.24 & 0.23 & 0.26 & $0.11^{*}$ \\
KRT33 & 5.96 & 0.69 & 0.73 & 0.05 & 4.00 & 0.58 & 0.65 & $0.11^{* *}$ & 5.02 & 0.81 & 0.78 & -0.05 & 5.95 & 0.59 & 0.58 & -0.02 \\
ADRB3 & 2.83 & 0.71 & 0.73 & 0.03 & 1.59 & 0.75 & 0.66 & -0.13 & 1.94 & 0.59 & 0.62 & 0.04 & 1.87 & 0.77 & 0.77 & -0.01 \\
DQA2 & 4.26 & 0.82 & 0.84 & $0.02^{*}$ & 2.96 & 0.66 & 0.62 & -0.06 & 4.48 & 0.95 & 0.81 & -0.18 & 2.83 & 0.82 & 0.83 & 0.00 \\
\hline Mean & 4.19 & 0.73 & 0.73 & - & 2.96 & 0.53 & 0.52 & - & 3.65 & 0.68 & 0.63 & - & 3.72 & 0.60 & 0.61 & - \\
\hline
\end{tabular}

\begin{tabular}{llllllllllllllllll}
\hline Population & \multicolumn{4}{c}{ Camplil Island } & \multicolumn{4}{c}{ Woodstock } & \multicolumn{4}{c}{ Hokonui I } & \multicolumn{4}{c}{ Hokonui II } \\
locus & $\mathbf{r}$ & $\boldsymbol{H}_{\boldsymbol{O}}$ & $\boldsymbol{H}_{\boldsymbol{E}}$ & $\boldsymbol{F}_{\mathrm{IS}}$ & $\mathbf{r}$ & $\boldsymbol{H}_{\boldsymbol{O}}$ & $\boldsymbol{H}_{\boldsymbol{E}}$ & $\boldsymbol{F}_{\mathrm{IS}}$ & $\mathbf{r}$ & $\boldsymbol{H}_{\boldsymbol{O}}$ & $\boldsymbol{H}_{E}$ & $\boldsymbol{F}_{\mathrm{IS}}$ & $\boldsymbol{r}$ & $\boldsymbol{H}_{\boldsymbol{O}}$ & $\boldsymbol{H}_{\boldsymbol{E}}$ & $\boldsymbol{F}_{\mathrm{IS}}$ \\
\hline KRTAP1-1 & 2.90 & 0.06 & 0.30 & $0.79^{* *}$ & 3.41 & 0.36 & 0.47 & 0.24 & 2.54 & 0.36 & 0.31 & -0.18 & 3.05 & 0.20 & 0.21 & 0.03 \\
KRT33 & 4.71 & 0.59 & 0.61 & 0.04 & 5.49 & 0.63 & 0.76 & $\mathbf{0 . 1 7}$ & 4.41 & 1.00 & 0.77 & -0.33 & 6.12 & 0.85 & 0.78 & -0.09 \\
ADRB3 & 2.06 & 0.53 & 0.51 & -0.37 & 2.38 & 0.80 & 0.66 & -0.21 & 1.97 & 0.55 & 0.44 & -0.26 & 1.79 & 0.69 & 0.61 & -0.13 \\
DQA2 & 3.03 & 0.74 & 0.76 & 0.02 & 4.33 & 0.94 & 0.81 & $-0.16^{* *}$ & 3.95 & 0.67 & 0.60 & -0.11 & 4.52 & 0.89 & 0.86 & -0.04 \\
\hline Mean & 3.18 & 0.48 & 0.55 & - & 3.90 & 0.68 & 0.68 & - & 3.22 & 0.65 & 0.53 & - & 3.87 & 0.66 & 0.62 & - \\
\hline
\end{tabular}

\begin{tabular}{|c|c|c|c|c|c|c|c|c|c|}
\hline \multirow{2}{*}{$\begin{array}{l}\text { Population } \\
\text { locus }\end{array}$} & \multicolumn{4}{|c|}{ Herbert } & \multicolumn{4}{|c|}{ Mohaka } & \multirow[t]{2}{*}{ Allele richness averages } \\
\hline & $r$ & $H_{O}$ & $H_{E}$ & $F_{\mathrm{IS}}$ & $r$ & $H_{O}$ & $H_{E}$ & $F_{\mathrm{IS}}$ & \\
\hline KRTAP1-1 & 2.61 & 0.30 & 0.26 & -0.16 & 3.00 & 0.33 & 0.30 & -0.11 & 3.19 \\
\hline KRT33 & 5.04 & 0.79 & 0.74 & -0.07 & 1.86 & 0.57 & 0.53 & -0.09 & 4.86 \\
\hline$A D R B 3$ & 1.90 & 0.46 & 0.38 & -0.20 & 2.00 & 0.67 & 0.53 & -0.29 & 2.03 \\
\hline$D Q A 2$ & 4.03 & 0.79 & 0.79 & -0.01 & 2.00 & 0.14 & 0.14 & - & 3.64 \\
\hline Mean & 3.40 & 0.59 & 0.54 & - & 2.22 & 0.43 & 0.38 & - & \\
\hline
\end{tabular}

${ }^{1}$ Significance of $F_{\mathrm{IS}}$ is indicated ${ }^{*} P<0.05,{ }^{*} P<0.01$, figure in bold character shows a tendency towards significance $(P<0.10)$; negative values indicate outbreeding while positive values indicate inbreeding; "-" represents data that could not be obtained 


\section{Discussion}

This is the first report describing DNA variation in feral sheep from NZ. The genes investigated in this study were chosen because they had previously been shown to influence wool traits [16], cold survival [17] and footrot resistance $[20,21]$. No new allele was identified for any of the genes in the feral sheep, suggesting that they will not be a source of alternative genetic variability, at least for these genes. The allelic richness and heterozygosity results (observed and expected) are comparable with those presented in previous studies of non-NZ wild sheep populations [32-34].

Although the feral sheep sampled were chosen so that they were representative of their populations, there is no guarantee that the farmers who maintain these populations on the NZ mainland have been able to maintain genetic diversity, especially because the flocks sizes are small compared to the original populations. Allele sharing among four offshore island flocks (Arapawa I and II, Pitt Island and Campbell Island) was significant for one gene but not necessarily for the same gene. Sheep populations from both Pitt and Campbell Islands, have undergone extensive size reduction before being relocated to the mainland and it is surprising that the level of inbreeding is not higher. In contrast, among the mainland Woodstock sheep, many different alleles are detected for $D Q A 2$ suggesting this flock is outbred, although other loci would need to be typed to confirm this. This is most likely due to the ongoing introduction of new genetic material from other Merino sheep which are typically farmed in areas adjacent to this population.

Sources of genetic variation in the feral sheep populations include founder effects, random drift, balancing selection, genetic bottlenecks, or combinations of these. Each will be discussed below.

Genetic drift may have affected these feral populations [35]. However, in some feral populations allele frequencies were similar to those in commercially farmed Merino sheep. This may not be surprising since both the feral and commercial merino sheep share the same Australian origin, and the two groups have been separated at most by 50 generations.

In some cases, allele frequencies in the feral populations were not "Merino-like" and tended to show greater similarity to allele frequencies in other common farmed sheep in NZ. This provides support for the anecdotal contention that these feral sheep have at times interbred with farmed non-Merino sheep.

There is evidence of genetic differences between groups of sheep on remote yet neighbouring islands. Chatham and Pitt Island sheep are thought to be descendents of the same founding Merino sheep, yet they show quite different allele frequencies for many of the genes studied here. Pitt and Chatham Island feral sheep have distinct wool colours but whether this is a result of the differences in the genes studied cannot be ascertained here.

Founder effects may influence the genetic diversity of feral populations [36]. It is apparent from early farming records that many of these flocks were initiated with 50 or less animals and hence the likelihood of finding rare alleles in the founding individuals might be small. Both $A D R B 3$ variants $D$ and $H$ are rare in farmed NZ sheep [17] and they are absent from the feral populations studied here.

An alternative explanation to the founder effect is that particular $A D R B 3$ alleles have been lost in the feral populations because they provide no selective advantage. This is called balancing selection and it reflects the situation where alleles are retained in a population by forms of selection such as heterozygote advantage, frequency-dependent selection [37] or selection varying in space and time that favours some alleles in certain environments [38]. ADRB3 alleles $A$ and $E$ are associated with cold survival, alleles $C$ and $F$ are linked to cold-related mortality, and allele $D$ has a strong association with cold-related mortality and total mortality [17]. The complete absence of $A D R B 3$ allele $D$ in the feral populations could be due to the fact that these flocks were exposed to cold climatic conditions during lambing and death of lambs carrying the allele.

A number of studies have suggested that feral sheep show few signs of susceptibility to infection by ectoparasites $[9,12]$ and fly strike [39] when compared to other domesticated sheep breeds. The reason why these animals may be more resistant to parasites remains unknown, but may involve genetic variation or reduced/ non-exposure to the pathogens.

Charbonnel and Pemberton [40] have suggested that infection with Teladorsagia circumcincta imposes a selection pressure in the Soay sheep of the island of Hirta in Scotland, and that this is reflected in the temporal divergence of the MHC genes over a relatively short period between 1988 and 2000. In the context of the results reported here, while the MHC allelic richness is at times low, in the absence of any data or evidence of on-going disease challenge it would be speculative to attempt to draw any conclusions. It should be noted that for $D Q A 2$, allele sharing was high within one island population but low within the mainland feral population, suggesting that the island population may have undergone some selection pressure.

Allele sharing at KRT33 and KRTAP1-1 was typically low suggesting the flocks may be outbred. Allele richness was highest for KRT33 indicating that the level of genetic diversity has remained quite high in these feral 
sheep populations. Feral sheep populations have some unique wool characteristics including at times a hairy birth-coat type, which has been shown to offer some advantage in improving lamb survival [41-43], the ability to shed their wool [7], tightly curled wool [12] and various coat colours and markings [8]. The genes responsible for these traits have yet to be identified, but may include some of the genes for keratins and KAPs that constitute wool fibre.

Genetic bottlenecks can cause loss of genetic diversity [44]. Like founder effects, they are largely responsible for the loss of low-frequency alleles and tend to increase the abundance of intermediate- and high-frequency alleles [45]. It is generally admitted that sheep populations from Pitt and Campbell Islands originated from a small number of founding animals that multiplied subsequently. After reaching a size of approximately 4000 sheep on both islands, genetic bottlenecks most likely occurred, when the majority of the sheep were slaughtered, and small numbers of sheep were transferred to NZ to create the flocks studied here. Thus these island populations may have been subject to both founder and bottleneck effects, but the data presented here does not show any strong evidence in favour of the historically documented bottlenecks and there are no obvious differences in allelic richness between the Pitt and Campbell island populations compared to the other feral sheep populations.

\section{Acknowledgements}

This research was supported by the Brian Mason Scientific and Technical Trust. We appreciate the time and effort of the farmers who maintain these sheep and for their generosity in supplying the DNA samples. We also thank members of the Gene-Marker Laboratory for completing the genotyping of samples.

\section{Author details}

'Department of Agricultural Science, Faculty of Agriculture and Life Sciences, PO Box 84, Lincoln University, Lincoln 7647, New Zealand. ${ }^{2}$ Environment Canterbury, PO Box 345, Christchurch 8140, New Zealand. ${ }^{3}$ Faculty of Sport and Health Sciences, Eastern Institute of Technology, Private Bag 1201, Napier, New Zealand.

\section{Authors' contributions}

GM supervised the collection of the genotype data, completed most of the analyses and drafted the manuscript. $\mathrm{HZ}$ and QF generated the DQA2 genotype data. NM provided the genotype data for the keratin genes used in this study. RF developed the ADRB3 genotyping methodology and generated the allele frequency data for the Merino and all breeds reference populations used in this study. She also helped revise this manuscript. JA applied for and was granted the funding that underpinned the collection of blood and data from the owners of these sheep. She designed the study and collected the blood samples from the different sheep populations identified. She was involved in typing KRTAP1-1 and assisted draft the manuscript. JRS provided completed parts of the statistical analysis and provided useful discussion on the results obtained from this study. He also assisted in the production of the final manuscript. JH helped develop the project in his capacity as research leader, provided comments on the grant proposal, and drafted the final manuscript. All authors read and approved the final manuscript.

Competing interests

The authors declare that they have no competing interests.
Received: 1 March 2010 Accepted: 21 December 2010

Published: 21 December 2010

\section{References}

1. Tapio M, Miceikiene I, Vilkki J, Kantanen J: Comparison of microsatellite and blood protein diversity in sheep: inconsistencies in fragmented breeds. Mol Ecol 2003, 12:2045-2056.

2. Mendelsohn R: The challenge of conserving indigenous domesticated animals. Ecol Econ 2003, 45:501-510.

3. Hedrick PW: Conservation genetics: where are we now? Trends Ecol Evol 2001, 16:629-636.

4. Rudge MR: A reserve for feral sheep on Pitt Island, Chatham group, New Zealand. NZ J Zool 1983, 10:349-364.

5. Rudge MR: Conserving feral farm mammals in New Zealand. NZ Agr SCi 1982, 16:157-160.

6. Rudge MR: Distribution, status and preservation of feral sheep in New Zealand. In Coloured sheep and their products. Edited by: Blair HT. Masterton: Austin and Warby Print Ltd; 1984:295-301.

7. Rudge MR: Feral Sheep. In The Hand Book of New Zealand Mammals. Edited by: King CM. New York: Oxford University Press; 2005:424-435.

8. Sumner R: Characteristics of some rare breeds of sheep. Rare Breeds NewZ, No.59, December 2002 (Rare Breeds Conservation Society of New Zealand; [http://www.rarebreeds.co.nz]

9. Whitaker $\mathrm{RH}$ : Feral sheep in New Zealand. In The value of feral farm mammals in New Zealand. Edited by: Whitaker RH, Rudge MR. Wellington: New Zealand Department of Lands and Survey; 1976:27-32.

10. Johns A: Hokonui wild merinos a unique gene pool. NZ Farmer 1980, 101:156.

11. Domestic Animal Diversity Information System (DADIS). Food and Agriculture Organization of the United Nations. [http://dad.fao.org/].

12. Parsons SR: The feral sheep (Ovis aries L.) of Woodstock Station, Canterbury, New Zealand. BSC (honours) dissertation. University of Canterbury, Department of Zoology 1980.

13. Bestic KL, Duncan RP, McGlone MS, Wilmshurst JM, Meurk CD: Population age structure and recent Dracophyllum spread on subantartic Campbell Island. NZ J Ecol 2005, 29:291-297.

14. Parsons YM, Cooper DW, Piper LR: Evidence of linkage between high glycine-tyrosine keratin gene loci and wool fibre diameter in a Merino half-sib family. Anim Genet 1994, 25:105-108.

15. Rogers GR, Hickford JGH, Bickerstaffe R: A potential QTL for wool strength located on ovine chromosome 11. Proceedings of the 5th World Congress on Genetics Applied to Livestock Production: 7-12 August; Guelph 1994, 21:291-294.

16. Itenge-Mweza TO, Hickford JG, Forrest RH, McKenzie GW, Frampton CM: Association of variation in the ovine KAP1.1, KAP1.3 and K33 genes with wool traits. Int J Sheep Wool Sci 2010, 58:1-20.

17. Forrest $\mathrm{RH}$, Hickford JGH, Frampton CM: Polymorphism at the ovine $\beta 3$-adrenergic receptor locus (ADRB3) and its association with lamb mortality. J Anim Sci 2007, 85:2801-2806.

18. Gaudieri S, Dawkins RL, Habara K, Kulski JK, Gojobori T: SNP profile within the human major histocompatibility complex reveals an extreme and interrupted level of nucleotide diversity. Genome Res 2000, 10:1579-1586.

19. Dean M, Carrington M, O'Brien SJ: Balanced polymorphism selected by genetic versus infectious human disease. Annu Rev Genomics Hum Genet 2002, 3:263-292

20. Escayg AP, Hickford JG, Bullock D: Association between alleles of the ovine major histocompatibility complex and resistance to footrot. Res Vet Sci 1997, 63:283-287.

21. Ennen S, Hamann H, Distl O, Hickford J, Zhou H, Ganter M: A field trial to control ovine footrot via vaccination and genetic markers. Small Rumin Res 2009, 86:22-25

22. Rogers GR, Hickford JG, Bickerstaffe R: Polymorphism in two genes for B2 high sulfur proteins of wool. Anim Genet 1994, 25:407-415.

23. Hickford JG, Zhou H, Fang Q: Haplotype analysis of the DQA genes in sheep: evidence supporting recombination between the loci. J Anim SCi 2007, 85:577-582.

24. Hickford JG, Zhou H, Slow S, Fang Q: Diversity of the ovine DQA2 gene. J Anim Sci 2004, 82:1553-1563.

25. Itenge-Mweza TO, Forrest RH, McKenzie GW, Hogan A, Abbott J, Amoafo O, Hickford JG: Polymorphism of the KAP1-1, KAP1.3 and K33 genes in Merino sheep. Mol Cell Probes 2007, 21:338-342. 
26. Sanguinetti CJ, Neto EM, Simpson AJG: Rapid silver-staining and recovery of PCR products separated on polyacrylamide gels. Biotechniques 1994, 17:915-919.

27. Weir BS, Cockerham CC: Estimating F-statistics for the analysis of population structure. Evolution 1984, 38:1358-1370.

28. Raymond M, Rousset F: GENEPOP (version 1.2): population genetics software for exact tests and ecumenicism. J Hered 1995, 86:248-249.

29. Guo SW, Thompson EA: Performing the exact test of Hardy-Weinberg proportion for multiple alleles. Biometrics 1992, 48:361-372.

30. Goudet J: FSTAT (vers. 1.2): a computer program to calculate F-statistics. J Hered 1995, 86:485-486.

31. Hurlbert SH: The nonconcept of species diversity: a critique and alternative parameters. Ecology 1971, 52:577-586.

32. Rendo F, Iriondo M, Jugo BM, Mazón LI, Aguirre A, Vicario A, Estonba A: Tracking diversity and differentiation in six sheep breeds from the North Iberian Peninsula through DNA variation. Small Rumin Res 2004, 52:195-202.

33. Tapio I, Tapio M, Grislis Z, Holm LE, Jeppsson S, Kantanen J, Miceikiene I, Olsaker I, Viinalass H, Eythorsdottir E: Unfolding of population structure in Baltic sheep breeds using microsatellite analysis. Heredity 2005, 94:448-456.

34. Lawson Handley L, Byrne K, Santucci F, Townsend S, Taylor M, Bruford MW, Hewitt GM: Genetic structure of European sheep breeds. Heredity 2007, 99:620-631.

35. Altukhov YP: Population genetics-Diversity and stability. Chur: Harwood Academic Publishers; 1990.

36. Hedrick P, Kalinowski ST: Inbreeding depression and conservation biology. Annu Rev Ecol Syst 2000, 32:139-162.

37. Charlesworth B: Fundamental concepts in genetics: effective population size and patterns of molecular evolution and variation. Nat Rev Genet 2009, 10:195-205.

38. Hedrick PW: Balancing selection. Curr Biol 2007, 17:R230-231.

39. Litherland AJ, Sorenson E, Niezen J, Bishop D: A pilot evaluation of shedding sheep breeds compared with non-shedding breeds for susceptibility to nematodes and flystrike. In Proceedings of the New Zealand Society of Animal Production: 11-13 February 1992; Lincoln Edited by: Elvidge DG 1992, 233-235.

40. Charbonnel N, Pemberton J: A long-term genetic survey of an ungulate population reveals balancing selection acting on MHC through spatial and temporal fluctuations ion selection. Heredity 2005, 95:377-388.

41. Purser AF, Karam HA: Lamb survival, growth and fleece production in relations to birth coat type among Welsh Mountain sheep. Anim Prod 1967, 9:75-85.

42. Guirgis RA, Kazzal NT, Zaghloul AM: The study of kemp succession in the adult fleece of two coarse-wool breeds of sheep in relations to the birth coat. J Agric Sci 1979, 93:531.

43. Alexander G: Temperature regulation in the new-born lamb. IV. The effect of wind and evaporation of water from the coat on metabolic rate and body temperature. Aust J Agric Res 1962, 13:82-99.

44. Luikart G, Sherwin WB, Steele BM, Allendorf FW: Usefulness of molecular markers for detecting population bottlenecks via monitoring genetic change. Mol Ecol 1998, 7:963-974

45. Luikart G, Allendorf FW, Cornuet JM, Sherwin WB: Distortion of allele frequency distributions provides a test for recent population bottlenecks. J Hered 1998, 89:238-247.

doi:10.1186/1297-9686-42-43

Cite this article as: McKenzie et al:: Genetic diversity of selected genes that are potentially economically important in feral sheep of New Zealand. Genetics Selection Evolution 2010 42:43.

\section{Submit your next manuscript to BioMed Central and take full advantage of:}

- Convenient online submission

- Thorough peer review

- No space constraints or color figure charges

- Immediate publication on acceptance

- Inclusion in PubMed, CAS, Scopus and Google Scholar

- Research which is freely available for redistribution

Submit your manuscript at www.biomedcentral.com/submit
Biomed Central 